\title{
Determination of the Prospective Teachers' Attitudes toward the Education of the Gifted Children
}

Nilgün METÍN*

\author{
Fatma Betül ȘENOL**
}

\author{
Esma INCE***
}

Received: 23 December 2015

Accepted: 02 August 2016

\begin{abstract}
The aim of this study is to determine the attitudes of prospective teachers toward gifted children's education. 490 prospective teachers, who are studying at the Education Faculty of Afyon Kocatepe University, participated in the research using correlational and comparative survey methods. $107(21,8 \%)$ of the participants are male, while $383(78,2 \%)$ of them are female. In order to determine the attitudes, "Giftedness and the Attitudes toward Gifted Education Scale" (Short-Revised form) was used. The final data were analyzed through ANOVA, Post Hoc, $t$ Test, frequencies and percentages As a result of the study, it was concluded that the attitudes of prospective teachers toward gifted children's education are positive. A significant difference was found out in prospective teachers' attitudes, which are related to "Needs of the Gifted and Support, and Being Against the Special Services for the Gifted,-one of the sub-dimensions of the scale- according to their departments. Another major difference -in favor of the female teachers- was found after comparing gender-based attitudes of the teachers related to "Being Against the Special Services for the Gifted". Besides, a significant difference was found in favor of the ones, who don't take inclusive courses when compared to students who take inclusive courses, in terms of "Creating Gifted Education Classrooms" $(\mathrm{p}<0.05)$.
\end{abstract}

Keywords: gifted children, attitude, prospective teacher.

\section{Extended Abstract}

Purpose and Significance: When the current studies related to the education of gifted children were analyzed, it can be clearly seen that gifted children are not able to meet their educational needs in general education schools and not enough opportunities are provided to make them improve their selves. It is necessary for teachers to enrich the education program by using different methods and techniques in order to meet the educational needs of gifted children. The attitudes of the teachers towards gifted children are highly critical for the students to improve their skills and abilities in an effective and productive education life. For this reason, it is important to raise awareness about the education of the gifted children to the teacher candidates who are still attending their education and to learn the level of their attitudes, in terms of the measures that can be taken in this regard. Accordingly, the aim of this study is to determine the attitudes of the teachers regarding the education of the gifted children.

\footnotetext{
* Prof. Dr., Hacettepe University, Ankara, Turkey, enmetin@ gmail.com

** Corresponding Author: Res. Assist., Afyon Kocatepe University, Afyonkarahisar, Turkey, fbetululu@ aku.edu.tr

*** Assistant Expert, Ministry of Family and Social Policies, Ankara, Turkey, esmaince@ hotmail.com
}

Citation Information

Metin, N., Şenol, F. B., \& İnce, E. (2017). Öğretmen adaylarının üstün yetenekli çocukların eğitimine yönelik tutumlarının belirlenmesi. Kuramsal Eğitimbilim Dergisi [Journal of Theoretical Educational Science], 10(1), 95-116. 
Methods: The participants of this study which was conducted by screening model consist of 490 teacher candidates who are studying in fourth grade in Afyon Kocatepe University, Faculty of Education, in 2014-2015 academic year. 107 (21,8\%) of the participants were male, while $383(78,2 \%)$ of them were female. 144 of the participants (29.4\%) were in the Pre-School Teaching, 59 (12.0\%) were in Turkish Language Teaching, 128 (26.1\%) were in Primary School Teaching, 91 (18.6\%) were in Social Studies Teaching and 68 of them (13.9\%) were studying Computer Teaching department. The data collection tool used in this survey consists of two parts. . The first section summarizes the purpose of the research, stating the confidentiality of responses and academic purposes, as well as a description of the participants voluntarily asking them to participate and a personal information form requested by the genders. In the second part, the "'Gifted Children and the Attitude Scale towards Gifted Education (Short-Revised Form)" (Tortop, 2014) was used. The original form of the scale developed by Gagne and Nedau (1985) consists of 34 items and six dimensions (The Needs of the Gifted and Support Dimension, Being Against the Special Services for the Gifted, Social Value of the Gifted, Exclusion and Insulation of the Gifted, Creating Classes for the Gifted, Class Gathering). Scale has been revised by some researchers (Siegel \& MCCoach, 2007; Chipego, 2004). Scale, of which validity and reliability studies were conducted by Donerlson (2008), was used as 27 items and 5 point likert scale. The adaptation of this scale to Turkish version was done by Tortop (2012) and the same researcher (Tortop, 2014b) shortened it by revising the scale. In this way, the scale consists of three factors and a short 14-item form. Although the cronbach alfa coefficient for all of the scale was 0.801, it was determined that "Needs and Supports of the Talented" was 0.724, "Resistance to Special Services for the Talents" was 0.614, and "Special Ability Classes Creation Dimension" was 0.749. The data obtained from the scale used were analyzed by using an SPSS statistical package program. In accordance with the goals of the study, personal information of the teachers who participated in the study was analyzed using frequency analysis. .The Kolmogorow Smirnow test was applied to find out whether the teacher candidates had a normal distribution of scores from the scale. Independent samples t test was conducted for teacher candidates' gender variables. Besides, one-way analysis of variance (ANOVA) was conducted for unrelated samples to determine whether there were any differences between the groups in which the teacher candidates had studied and the related group variables. In all the statistical studies performed, the level of significance was accepted as 0.05 and the Post Hoc test was applied to determine the groups in which the significant difference is between.

Results and Discussion: The mean of the scale scores of the teacher candidates' general scale $(\bar{X}=3.53)$ and the average of the scale scores of the needs and support dimension of the talented students $(\bar{X}=3.74)$; The average of the scale scores for the dimension of being opposed to special services for talents $(\bar{X}=3.63)$; The average of the scale scores 
for Creating Special Ability Classes dimension $(\bar{X}=3.09)$ and their attitude is positive or indecisive. It is noteworthy in the study that prospective teachers' attitudes towards the education of the gifted children are not over 4.00, which means "very positive". Nowadays, the prospective teachers learn superficial knowledge about the gifted children in "Special Education" courses. However, they don't take a specific on how to teach these children according to their branches in the educational programs to be implemented. Hence, it is considered that the attitudes of the prospective teachers are not very positive. When the attitudes of prospective teachers to gifted education are examined according to the division they have studied, a significant difference was found between attitudes towards the needs of gifted and talented and support for gifted and talented individuals. The attitudes of the prospective teachers in the department of primary school teachers on the needs of the talented and against the special services to support and superior ability were high. Classroom teachers are adults who are responsible of children's education from the age of 7 to 11 and have spent most of their times during a day, other than their parents. Therefore, it might be considered that their attitudes towards the education for gifted children are high. It can be said that the attitudes of the prospective teachers on the subscale of being against the special services to the talents are positive. The positive attitude of prospective teachers to this subdimension may be indicative of the fact that they know that gifted children have different needs in terms of their developmental characteristics and that each child should be supported under the principle of equality in education. Also, a significant difference in favor of the female teachers was found after comparing gender-based attitudes of the teachers related to "Being Against the Special Services for the Gifted Dimension". When the attitudes of the prospective teachers to gifted education are examined according to whether they have taken a course of integration or not; there was a significant difference in favor of prospective candidates among those who did and did not take the mainstreaming lesson on the "Creating Special Ability Classes" subdimension of the candidate teachers. Students who do not take the mainstreaming course in parallel with the general judge of the community may think that it would be more beneficial to place children who are in special need of the disassociated classes.

Conclusion: According to the results of the study, the attitudes of the prospective teachers towards the education of the gifted children were "positive" and "indecisive". It is necessary that not only the teacher candidates should be informed about the characteristics of the gifted children and their educational needs in a more detailed way, but also clear additions - within the scope of compulsory courses - should be inserted into education programs. 


\title{
Öğretmen Adaylarının Üstün Yetenekli Çocukların Eğitimine Yönelik Tutumlarının Belirlenmesi
}

\author{
Nilgün METíN* $\quad$ Fatma Betül ŞENOL** Esma İNCE***
}

Makale Gönderme Tarihi: 23 Aralık 2015

Makale Kabul Tarihi: 02 August 2016

\begin{abstract}
ÖZ: $\mathrm{Bu}$ araştırmanın amacı, öğretmen adaylarının üstün yetenekli çocukların eğitimine yönelik tutumlarının belirlenmektir. Araştırmanın modeli, ilişsisel tarama modelidir. Araştırmanın çalışma grubunu 2014 - 2015 eğitim öğretim yılı bahar döneminde Afyon Kocatepe Üniversitesi, Eğitim Fakültesi, dördüncü sınıfa devam etmekte olan 490 öğretmen adayı oluşturmaktadır. Öğretmen adaylarının 107'si erkek (\%21.8), 383'ü kadın (\%78.2)'dır. Araştırmanın veri toplaması aşamasında öğretmen adaylarının tutumların belirlenmesi için "Üstün Yeteneklilik ve Üstün Yetenekli Eğitime İlişsin Tutum Ölçeği (Kısa - Revize Form)" kullanılmıştır. Ölçekten elde edilen veriler ANOVA, Post Hoc, t testi, frekans ve yüzde dağılımıyla analiz edilmiştir. Araştırmanın sonucunda öğretmen adaylarının üstün yetenekli çocukların eğitimine yönelik tutumlarının olumlu düzeyde olduğu saptanmıştır. Öğretmen adaylarının bölümlerine göre ölçeğin alt boyutlarından Üstün Yeteneklilerin İhtiyaçları ve Destek ve Üstün Yeteneklilere Özel Hizmetlere Karşı Olma boyutlarına ilişkin tutumları arasında anlamlı bir fark bulunmuştur. Öğretmen adaylarının cinsiyetlerine göre Üstün Yeteneklilere Özel Hizmetlere Karşı Olma boyutuna ilişkin tutumları arasında kadınların lehine anlamlı bir fark bulunmuştur. Öğretmen adaylarının "Özel Yetenek Sınıfları Oluşturma” alt boyutuna ilişkin kaynaştırma dersi alan ve almayanlar arasında, ders almayan adaylarının lehine anlamlı farklılık bulunmuştur $(\mathrm{p}<0.05)$.
\end{abstract}

Anahtar kelimeler: üstün yetenekli çocuk, tutum, ögretmen adayı.

\section{Giriş}

Bir toplumun gelişmesinde ve ilerlemesinde geleceğin en önemli insan gücü olan bugünün üstün yetenekli çocuklarını keşfederek ve eğiterek, potansiyellerini en üst düzeye taşımalarını sağlamak, çağdaş eğitim sisteminin en önemli sorumluluklarından birisidir (Şenol, 2011). Zihinsel yetenekleri bakımından yaşıtlarına göre daha yüksek düzeyde performans gösteren üstün yetenekli çocuklar, ilgi ve yetenekleri ölçüsünde farklılaştırılmış bir eğitime ya da programa gereksinim duyarlar. Üstün yetenekliler, ileri düzeyde zihinsel yetenek, çeşitli alanlarda özel yetenek, duyarlılık, yaratıcılık ve yoğun motivasyon gibi özellikleri ile diğer bireylerden ayırt edilebilirler (Gökden Kaya \& Ataman, 2012).

Eğitim; ailede başlayan ve okul ortamında devam eden bir süreçtir. Ailelerden sonra üstün yetenekli çocukların fark edilmesinde en büyük role sahip olan kişiler öğretmenlerdir. Çünkü çocuk, okul öncesi eğitim kurumuna başladığı andan itibaren günün önemli bir kısmını öğretmeni ile geçirmeye başlamaktadır (Robinson, Shore \& Enersen, 2014). Bu kurumlardaki çocuklar içerisinde bulunan üstün yetenekli çocukların ailelerinin bilgilendirilmesi, çocukların yeteneklerinin geliştirilmesi oldukça önemlidir. "Her çocuğun bireysel farklılığı vardır" ilkesi doğrultusunda üstün yetenekleri birbirlerinden farklılık gösteren çocuklardan bazıları, okul öncesi dönemde öğretmenleri tarafından fark edilebilirken, çeşitli nedenlerle bazı çocuklardaki üstün yeteneklilik ilköğretim ya da orta öğretim yıllarında fark edilebilmektedir (Kıldan,

\footnotetext{
* Prof. Dr., Hacettepe Üniversitesi, Ankara, Türkiye, enmetin@gmail.com

** Sorumlu Yazar: Arş. Grv., Afyon Kocatepe Üniversitesi, Ankara, Türkiye, fbetululu@aku.edu.tr

${ }^{* * *}$ Uzman Yardımcısı, Aile ve Sosyal Politikalar Bakanlığı, Ankara, Türkiye, esmaince@hotmail.com
} 
2011). Üstün yetenekli çocuklarla ilgili en önemli konuların başında farklılığı fark edilen çocukların yeteneklerini geliştirebilmeleri için düzenli ve sistemli bir eğitimin oluşturulması gerekliliğidir. Sistemli eğitim için çocuğun kendini gerçekleştirebileceği, verim alabileceği eğitim ortamlarının oluşturulması gerekmektedir. Eğitim ortamında üstün yetenekli çocukların üstün yönlerinin keşfedilebilediği kendilerini güvenli ve rahat hissedebilecekleri olumlu atmosfer oluşturulması oldukça önem taşımaktadır (Maker \& Nielson, 1996). Olumlu eğitim ortamı çocukların akademik başarılarını, sosyal, duygusal ve bilişsel gelişimlerini, motivasyonlarını, ilgilerini ve tutumlarını olumlu yönde etkilemektedir (Clark, 1997; Cline \& Schwartz, 1999; Esposito, 1999; Megay-Nespoli, 2001; Morris, 1987; Rao \& Lim, 1999). Bu nedenle okul öncesi öğretmenleri gibi ilerleyen yıllarda sınıf ve branş öğretmenlerine de önemli görevler düşmektedir. Üstün yetenekli çocukların başarılı bir okul ortamında olabilmeleri, var olan yeteneklerinin keşfedilmesi ve geliştirmesi için uygun teknik ve yöntemlerin kullanılarak öğretimlerin gerçekleştirilmesi, ancak öğretmenlerin her öğrenciyi yakından tanıması ve üstün yetenekli çocukların özellikleri ve eğitimleri konusunda bilgi sahibi olmaları ile mümkündür (Çaylak, 2012). Kıldan (2011) yaptığı bir çalışmasında okul öncesi öğretmenlerinin, üstün yetenekli çocuklar hakkında kısmen bilgi sahibi olduklarını ifade etmiştir. Ayrıca üstün yetenekli çocukların akranlarından farklı olarak çeşitli eğitim süreçlerinden geçmeleri gerektiğini belirtmiş; okul öncesi öğretmenlerinin üstün yetenekli çocuklar hakkındaki bilgi seviyelerinin daha üst düzeyde olması gerektiği ve bu konuda çeşitli hizmet içi eğitim seminerlerine gereksinim duyulduğunu vurgulamıştır. Akar ve Şengil Akar (2012)'nin yaptığ çalışmada ise ilköğretim öğretmenlerinin üstün yetenek kavramı ve üstün yetenekli öğrenciler hakkında yeterli düzeyde bilgiye sahip olmadıkları bulunmuştur. Bu durum üstün yetenekli öğrencileri fark etme ve onları ilgili programlara aday gösterebilme konularında da yeterli olamayacaklarının bir göstergesi olarak ifade edilmiştir. Yine benzer bir araştırma üstün yetenekli çocukları olan veliler ve sınıf öğretmenleri ile yapılmış ve bu çocukların tanılama-teşhisleri, özellikleri ve eğitimleri konusunda yeterince bilgiye sahip olmadıkları, çocukların eğitimi ile ilgili hiçbir eğitim almadıkları, bu nedenle onlara özgü özel okullarda eğitim almalarını istedikleri saptanmıştır (Şentürk, Bayat \& K1lıçarslan, 2012). Clinkenbeard ve Kollhoff (2001), Sak (2011) ve Tomlinson (1996) gibi araştırmacıların yaptıkları çalışmalar incelendiğinde üstün yetenekli çocuklara verilen eğitim ve bu eğitimin onların akademik ve sosyal, duygusal gereksinimlerini karşılamaya yönelik etkileri hakkında öğretmenlerin bilgi eksikliğinin olduğu görülmektedir.

Öğretmenlerin üstün yetenekli çocukların potansiyellerine uygun eğitim ortamı oluşturmalarında üstün yetenekli çocuklara yönelik tutumları, onların etkin ve verimli bir eğitim hayatı içerisinde beceri ve yeteneklerini geliştirmeleri açısından önem taşıdı̆̆ 1 söylenebilir. Yapılan araştırmalar incelendiğinde öğretmenlerin üstün yetenekli çocuklara yönelik tutumları üstün yetenekli çocuklarla sınıf içerisindeki etkileşimlerine (Albion \& Ertmer, 2002), çocukların performanslarını geliştirmek için kullandıkları öğretim yöntemlerine, seçtikleri etkinlikleri, kullandıkları araç gereçleri etkilediği görülmektedir (Curtis, 2005). Ayrıca öğretmenlerin tutumları üstün yetenekli çocukların 
gösterdikleri performanslarında etkili olduğunu gösteren araştırmalar bulunmaktadır (Gerow, Bordens \& Blanche-Payne, 2007; Godwin, 2002; Megay-Nespoli, 2001; Neumeister, Adams, Pierce \& Cassidy, 2007; Rao \& Lim, 1999).

Konu ile ilgili yapılan çalışmalar incelendiğinde öğretmen adaylarının üstün yetenekli çocuklara yönelik tutumlarının incelendiği araştırmaların oldukça az olduğu görülmektedir. Öğretmen adaylarına üstün yetenekli çocukların eğitimleri konusunda farkındalık kazandırmak, tutumlarının ne düzeyde olduğunu öğrenmek ve üstün yetenekli çocukların mevcut potansiyellerini koruyarak geliştirebilecek öğretmenlerin meslek yaşamına başlamadan önce bu çocuklara yönelik olumlu tutum geliştirmeleri açısından önem taşımaktadır.

$\mathrm{Bu}$ kapsamda araştırmanın genel amacı, üstün yetenekli çocukların eğitimine ilişkin öğretmen adaylarının tutumlarının belirlenmesidir. Alt problemleri ise şu şekildedir;

- Öğretmen adaylarının üstün yetenekli çocukların eğitimine ilişkin tutumları, öğrenim gördükleri bölüme göre farklılaşmakta mıdır?

- Öğretmen adaylarının üstün yetenekli çocukların eğitimine ilişkin tutumları, cinsiyetlerine göre farklılaşmakta mıdır?

- Öğretmen adaylarının üstün yetenekli çocukların eğitimine ilişkin tutumları, kaynaştırma dersi alıp almama durumlarına göre farklılaşmakta mıdır?

\section{Yöntem}

\section{Araştırmanın Modeli}

$\mathrm{Bu}$ çalışmada ilişkisel tarama modeli kullanılmıştır. Tarama modelinin bir türü olan ilişkisel tarama modeli, iki ve daha çok sayıdaki değişken arasında birlikte değişim varlığını ve/veya derecesini belirlemeyi amaçlayan araştırma (Karasar, 2005).

\section{Çalışma Grubu}

Katılımcılar, 2014 - 2015 eğitim öğretim yılında Afyon Kocatepe Üniversitesi, Eğitim Fakültesi'nde dördüncü sınıfta öğrenim görmekte olan 490 öğrenciden (öğretmen adayından) oluşmaktadır. Bu öğretmen adaylarının hepsi zorunlu ders kapsamında “Özel Eğitim” isimli dersi almıştır. Katılımcıların 107'si erkek (\%21.8), 383'ü kadındır (\%78.2). Öğretmen adaylarının 144'ü (\%29.4) Okul Öncesi Eğitimi, 59'u (\%12.0) Türkçe Eğitimi, 128'i (\%26.1) Sınıf Eğitimi, 91'i (\%18.6) Sosyal Bilgiler Eğitimi, 68'i (\%13.9) Bilgisayar ve Öğretim Teknolojileri Eğimi programlarında öğrenim görmektedirler.

\section{Veri Toplama Aracı}

Araştırmada veri toplama aracı olarak, öğretmen adaylarının demografik özelliklerinin yer aldığ 1 Kişisel Bilgi Formu ve araştırmanın probleminin çözümü için gerekli bilgileri toplamada Üstün Yeteneklilik ve Üstün Yetenekli Eğitime İlişkin Tutum Ölçeği kullanılmıştır. 
Kişisel bilgi formu. Araştırmacılar tarafından geliştirilen formda öğretmen adaylarının cinsiyeti, öğrenim gördükleri program, daha once kaynaştırma dersi alıp almama durumuna ilişkin sorular yer almaktadır.

Üstün yeteneklilik ve üstün yetenekli eğitime ilişkin tutum ölçeği (ÜYETÖ). Üstün Yeteneklilik ve Üstün Yetenekli Eğitimine İlişkin Tutum Ölçeği, ilk defa Gagne ve Nadeau (1985) tarafından geliştirilmiştir (Opinions About the Gifted and Their Education) ve ölçeğin orjinali 34 maddedir. ÜYETÖ, Üstün Yeteneklilerin İhtiyaçları ve Destek Boyutu, Üstün Yeteneklilere Özel Hizmetlere Karşı Olma, Üstün Yeteneklilerin Toplumsal Değeri, Üstün Yeteneklilerin Dışlanması ve İzolasyon, Özel Yetenek Sinıfları Oluşturma, Sınıf Atlatma olmak üzere altı boyuttan oluşmaktadır. ÜYETÖ, bazı araştırmacılar tarafından (Chipego, 2004; Siegle \& McCoach, 2004) yeniden revize edilmiştir. Donerlson (2008) tarafından geçerlik ve güvenilirlik çalışmaları yapılan ÜYETÖ, 27 madde halinde, 5 li likert tipte kullanılmıştır ve Cronbach alfa iç tutarlılık katsayısı 0.91 bulunmuştur. Bu ölçeğin Türkçe versiyonuna adaptasyonu Tortop (2012) tarafından yapılmıştır ve aynı araştırmacı (Tortop, 2014b) ölçeği revize ederek kısaltmıştır. Böylelikle ölçeğin üç faktörden oluşan yapısı ve 14 maddelik kısa formu oluşturulmuştur. Ölçeğin tümünün Cronbach $\alpha$ katsayısı 0.801 olurken, "Üstün Yeteneklilerin İhtiyaçları ve Destek Boyutu" 0.734, "Üstün Yeteneklilere Özel Hizmetlere Karşı Olma Boyutu” 0.614, “Özel Yetenek Sınıfları Oluşturma Boyutu” 0.749 olarak belirlenmiştir. Araştırmada kullanılan ölçeğin, alt boyutlarının güvenirlik katsayıları ve maddelerin madde toplam korelasyonları aşağıdaki tabloda belirtilmiştir. 
Tablo 1

ÜYETÖ’nin Alt Boyutlarının Madde Toplam Korelasyonlarl ve Cronbach $\alpha$ Katsayılart

\begin{tabular}{lccc}
\hline$\ddot{U}$ YETÖ & $\begin{array}{c}\text { Madde } \\
\text { No }\end{array}$ & $\begin{array}{c}\text { Madde-Toplam } \\
\text { Korelasyonu }\end{array}$ & $\begin{array}{c}\text { Alfa } \\
\text { Katsayıs }\end{array}$ \\
\hline & $\mathrm{m} 5$ & 0.544 & \\
Üstün Yeteneklilerin İhtiyaçları ve Destek & $\mathrm{m} 6$ & 0.480 & \\
& $\mathrm{~m} 7$ & 0.453 & \\
& $\mathrm{~m} 8$ & 0.480 & 0.734 \\
\hline Üstün Yeteneklilere Özel Hizmetlere Karşı Olma & $\mathrm{m} 9$ & 0.391 & \\
& $\mathrm{~m} 13$ & 0.387 & \\
& $\mathrm{~m} 14$ & 0.401 & 0.614 \\
Özel Yetenek Sinıfları Oluşturma & $\mathrm{m} 2$ & 0.469 & \\
& $\mathrm{~m} 12$ & 0.3606 & \\
& $\mathrm{~m} 1$ & 0.376 & 0.749 \\
& $\mathrm{~m} 4$ & 0.400 & \\
\hline
\end{tabular}

Güvenirlik katsayısı, 0 ile +1 arasında değişkenlik göstermektedir. Güvenirlik katsayısının 1'e yakın değerler alması güvenirliğin ve maddeler arasında iç tutarlılığın yüksek olduğu anlamına gelmektedir.

Ölçekteki her bir madde tamamen katılıyorum (5), kesinlikle katılmıyorum (1) puan olacak şekilde puanlanmıştır. Ölçek puanlarını elde etmek için, her bir maddeye ilişkin puanlar toplanmış ve toplam puan madde sayısına bölünerek tutum puanları 1-5 arasında değişkenlik gösterecek şekilde değerlendirilmiştir. Ölçekten elde edilen tutum puanlarının 4.00 üzerinde olması çok olumlu tutuma, 2.00 altında olması ise çok olumsuz tutuma işaret etmektedir Tutum puanları 2.75 ile 3.25 arasında olması ise kararsızlık durumunu göstermektedir (Gagné, 1991).

\section{Verilerin Analizi}

Uygulanan ölçekten elde edilen veriler SPSS programı kullanılarak çözümlenmiştir. Araştırmanın amaçlarına uygun olarak, araştırmaya katılan öğretmen adaylarının kişisel bilgileri frekans analizi kullanılarak analiz edilmiştir. Öğretmen adaylarının ölçekten aldıkları puanların normal dağılım gösterip göstermediğini öğrenmek amaciyla Kolmogorow Smirnow testi uygulanmıştır. $\mathrm{Bu}$ test sonucunda anlamlılık düzeyi 0,05'den büyük çıktığı için ölçekten alınan puanların normal dağıldığ1 belirlenmiştir. Normallik testi sonrasında denek sayısı da dikkate alınarak istatistiksel 
testlerin seçimi yapılmıştır. Öğretmen adaylarının cinsiyet değişkeni için İlişkisiz Örneklemler t Testi (Independent Samples t Test) yapılmıştır. Öğretmen adaylarının öğrenim gördükleri bölümler ile ilgili grup değişkenleri arasında farklılık olup olmadığını belirlemek için İlişkisiz Örneklemler Için Tek Faktörlü Varyans Analizi (one way ANOVA) çözümlemesi yapılmıştır. Yapılan tüm istatiksel çalışmalarda anlamlılık düzeyi 0,05 olarak kabul edilmiş olup anlamlı farklılı̆̆ın hangi gruplar arasında olduğunun belirlenmesi amacıyla Post Hoc testi uygulanmıştır.

\section{Bulgular ve Tartışma}

Araştırmanın temel problemi olan "Öğretmen adaylarının üstün yetenekli eğitimine yönelik tutumları nedir?" sorusuna ilişkin araştırmaya katılan öğretmen adaylarının ölçeğin geneline ve Üstün Yeteneklilerin İhtiyaçları ve Destek Boyutu, Üstün Yeteneklilere Özel Hizmetlere Karşı Olma, Özel Yetenek Sinıfları Oluşturma boyutlarına ilişkin tutumlarının ortalama istatistikleri Tablo 2'de gösterilmiştir.

Tablo 2

Öğretmen Adaylarının Üstün Yetenekli Eğitime İlişkin Tutum Ortalamaları

\begin{tabular}{lccc}
\hline$\ddot{U}$ YETÖ & Ortalama & ss & Düzey \\
\hline Üstün Yeteneklilerin İhtiyaçları ve Destek & 3.74 & 0.66 & Olumlu \\
Üstün Yeteneklilere Özel Hizmetlere Karşı Olma & 3.63 & 0.85 & Olumlu \\
Özel Yetenek Sinıfları Oluşturma & 3.09 & 0.81 & Kararsız \\
Toplam & 3.53 & 0.56 & Olumlu \\
\hline
\end{tabular}

Öğretmen adaylarının ölçeğin geneline ilişkin ölçek puanlarının ortalaması $(\bar{X}=3.53)$ ve Üstün Yeteneklilerin İhtiyaçları ve Destek Boyutuna ilişkin ölçek puanlarının ortalaması ( $\bar{X}=3.74)$; Üstün Yeteneklilere Özel Hizmetlere Karşı Olma boyutuna ilişkin ölçek puanlarının ortalaması $(\bar{X}=3.63)$; Özel Yetenek Sınıfları Oluşturma boyutuna ilişkin ölçek puanlarının ortalaması $(\bar{X}=3.09)$ olup, genel tutumları olumlu veya kararsızlık durumu olarak yorumlanabilir.

Yapılan araştırmada öğretmen adaylarının üstün yetenekli çocukların eğitimine yönelik tutumlarının "çok olumlu" anlamı taşıyacak şekilde 4.00'ün üzerinde olmaması dikkat çekmektedir. Günümüzde öğretmen adayları üstün yetenekli çocuklarla ilgili bilgiyi “Özel Eğitim” dersi içinde yüzeysel olarak öğrenmektedir. Ancak uygulanacak eğitim programlarında branşlarına göre bu çocukların nasıl yönlendirebileceklerine ilişkin özgün bir ders almamaktadırlar. Bu nedenle öğretmen adaylarının tutumlarının çok olumlu düzeyde olmadığ 1 düşünülmektedir. İncelenen araştırma ve kaynaklarda öğretmenlerin üstün yetenekli çocukların eğitimi konusunda eksiklikleri olduğu bildirilmektedir (Gagné, 1991; Hansen \& Feldhusen, 1994; Levent, 2014; Tortop, 2014a). Öğretmen adaylarına eğitimleri esnasında konuyla ilgili bilgi verilmesi ve sahada çalışan öğretmenlere hizmet içi eğitim verilmesi ile tutumlarda artış 
gösterebileceği bazı çalışmalarda belirtilmiştir (Gross, 1994; Lassig, 2003 aktaran Tortop, 2014b). Bu durumda eğitim fakültelerinde öğrenimlerine devam etmekte olan öğretmen adaylarına üstün yetenekli çocukların özellikleri ve eğitim gereksinimleri hakkında bir bilgilendirmenin yapılması ve genel olarak tutumlarının olumlu düzeyde iyileştirilmesi için öğretmenlik eğitim programlarına zorunlu ders kapsamında eklemelerin yapılması gerekmektedir. Tortop (2014a) da yaptığı araştırmada öğretmen adaylarının üstün yetenekli çocukların eğitimine yönelik tutumlarının düşük olduğu sonucuna ulaşmiştır.

Öğretmenlerin ve öğretmen adaylarının üstün yetenekli öğrencileri fark etmesi, potansiyellerini en üst seviyeye çıkarabilmesi ve olumlu tutum geliştirebilmeleri için bu konuda bilgi sahibi olmalar1 gerekmektedir (Levent, 2014). Winebrenner (2001), üstün yetenekli çocukların eğitimi ile ilgili eğitim alan ve üstün yetenekli çocuklarla çalışan öğretmenlerin mesleki doyumlarının daha yüksek olduğunu belirtmektedir. Mesleki doyumu yüksek olan bir öğretmen olumlu tutumlar geliştireceği için öğretmen adaylarının eğitimleri esnasında üstün yetenekli çocuklarla ilgili ders almaları gerektiği önemle vurgulanmalıdır.

Hansen ve Feldhusen (1994) yaptıkları çalışmada üstün yetenekli öğrencilerin eğitimine yönelik eğitim almış ve almamış öğretmenler karşılaştırılmış, araştırmanın sonucunda eğitim almış öğretmenlerin daha olumlu sınıf ortamı sağladıkları sonucuna ulaşılmışlardır. Benzer şekilde Allodi ve Rydelius (2008) yaptıkları araştırmada özel eğitim dersi alan öğretmen adaylarının üstün yetenekli çocukların eğitimine yönelik olumlu tutum geliştirdiklerini ortaya koymuştur. Lassig (2003), öğretmenlerin üstün yetenekli çocuklar ile ilgili eğitim almalarının üstün yetenekli çocukların eğitimine yönelik tutumlarının olumlu yönde etkileyebileceğini belirtmektedir. Öğretmenlerin bilgi eksikliğinden dolayı olumlu tutumlar geliştiremediklerini gösteren bir çalışma da Bianco (2005) tarafindan yapılmıştır ve bu çalışmada öğretmenlerin üstün yetenekli çocukları önerirken sahip oldukları tutumlar incelenmiştir. Yakmacı Güzel (2009) de öğretmenlerle yaptığı bir araştırmada, öğretmenlerin üstün yetenekli çocukların toplum için önemli olduğu, bu çocukların bazı haklara sahip olduğu ve eğitim gereksinimlerinin karşılanması gerektiğine kuvvetle katıldıkları bildirilmiştir. Eraslan Çapan (2010) yaptığı çalışmada öğretmen adaylarının üstün yetenekli çocukların eğitimine ilişkin kendi sorumluluklarını kabul ederek, üstün yetenekli çocukların eğitimine yönelik olumlu tutum gösterdiklerini belirtmiştir. Troxclair'in (2013) öğretmen adayları ve McCoach ve Siegle (2007)'nin öğretmenler ile yapmış olduğu araştırmada, bu çalışmada kullanılan ölçeğin altı boyutlu formunu kullanmış ve sonuçta, bu çalışmanın sonuçlarını destekler şekilde, belirtilen boyutlara ait öğretmen adaylarının tutumlarının olumlu olduğu sonucuna ulaşmıştır. Ayrıca Rash ve Miller (2000)'in yaptı̆̆ çalışmada, öğretmenlerin üstün yetenekli çocuklara yönelik tutumlarını ve olumlu sınıf ortamı oluşturmaları üstün yetenekli çocuklarla çalışma saatleri arttıkça arttığı belirtilmektedir.

Araştırmada "Öğretmen adaylarının üstün yetenekli eğitimine ilişkin tutumları okudukları bölüme göre farklılaşmakta mıdır?” alt problemine ilişkin bulgular tek yönlü varyans analizi ile test edilmiş ve sonuçları Tablo 3'te gösterilmiştir. 
Tablo 3

Öğretmen Adaylarının Üstün Yetenekli Çocukların Ĕgitimine Ilişkin Tutumlarının Öğrenim Gördükleri Programlara Göre ANOVA Sonuçları

\begin{tabular}{|c|c|c|c|c|c|c|c|}
\hline ÜYETÖ & & $n$ & Ortalama & ss & $\boldsymbol{F}$ & $p$ & Anlamlı Fark \\
\hline \multirow{6}{*}{$\begin{array}{l}\text { Üstün } \\
\text { Yeteneklilerin } \\
\text { İhtiyaçları ve } \\
\text { Destek }\end{array}$} & Okul Öncesi Eğitimi & 144 & 3.66 & 0.64 & \multirow{6}{*}{3.717} & \multirow{6}{*}{$0.005^{*}$} & \\
\hline & Türkçe Eğitimi & 59 & 3.54 & 0.69 & & & Öncesi \\
\hline & Sınıf Eğitimi & 128 & 3.88 & 0.62 & & & Eğitimi - Sınıf \\
\hline & $\begin{array}{l}\text { Sosyal Bilgiler } \\
\text { Eğitimi }\end{array}$ & 91 & 3.81 & 0.69 & & & $\begin{array}{l}\text { Eğitimi } \\
\text { *Türkçe Eğitimi - } \\
\text { Sınıf Eğitimi }\end{array}$ \\
\hline & $\begin{array}{l}\text { Bilgisayar ve } \\
\text { Öğretim } \\
\text { Teknolojileri } \\
\text { Eğitimi }\end{array}$ & 68 & 3.73 & 0.63 & & & $\begin{array}{lr}\text { *Türkçe } & \text { Eğitimi - } \\
\text { Sosyal } & \text { Bilgiler } \\
\text { Eğitimi } & \end{array}$ \\
\hline & Toplam & 490 & 3.74 & 0.66 & & & \\
\hline \multirow{6}{*}{$\begin{array}{l}\text { Üstün } \\
\text { Yeteneklilere } \\
\text { Özel } \\
\text { Hizmetlere } \\
\text { Karşı Olma }\end{array}$} & Okul Öncesi Eğitimi & 144 & 3.70 & 0.82 & \multirow{6}{*}{2.590} & \multirow{6}{*}{$0.036^{*}$} & \\
\hline & Türkçe Eğitimi & 59 & 3.57 & 0.84 & & & \\
\hline & Sınıf Eğitimi & 128 & 3.76 & 0.79 & & & 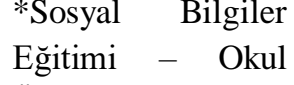 \\
\hline & Sosyal Bilgiler & 91 & 3.41 & 0.95 & & & Öncesi Eğitimi \\
\hline & $\begin{array}{l}\text { Bilgisayar ve } \\
\text { Öğretim } \\
\text { Teknolojileri } \\
\text { Eğitimi }\end{array}$ & 68 & 3.64 & 0.84 & & & $\begin{array}{l}\text { Eğitimi } \\
\text { Sınıf Eğitimi }\end{array}$ \\
\hline & Toplam & 490 & 3.63 & 0.85 & & & \\
\hline \multirow{6}{*}{$\begin{array}{l}\text { Özel Yetenek } \\
\text { Sinıfları } \\
\text { Oluşturma }\end{array}$} & Okul Öncesi Eğitimi & 144 & 3.04 & 0.75 & \multirow{6}{*}{0.950} & \multirow{6}{*}{0.435} & \multirow{6}{*}{ Yok } \\
\hline & Türkçe Eğitimi & 59 & 3.04 & 0.91 & & & \\
\hline & Sınıf Eğitimi & 128 & 3.14 & 0.82 & & & \\
\hline & $\begin{array}{l}\text { Sosyal Bilgiler } \\
\text { Eğitimi }\end{array}$ & 91 & 3.01 & 0.93 & & & \\
\hline & $\begin{array}{l}\text { Bilgisayar ve } \\
\text { Öğretim } \\
\text { Teknolojileri } \\
\text { Eğitimi }\end{array}$ & 68 & 3.22 & 0.68 & & & \\
\hline & Toplam & 490 & 3.08 & 0.81 & & & \\
\hline
\end{tabular}

*p<0.05

Sınıf Eğitimi Programı'nda öğrenim gören öğretmen adaylarının Üstün Yeteneklilerin İhtiyaçları ( $\bar{X}=3.88$ ) ve Destek ve Üstün Yeteneklilere Özel Hizmetlere Karşı Olma ( $\bar{X}=3.76$ ) boyutlarına ilişkin tutumları; Bilgisayar ve Öğretim Teknolojileri Eğitimi Programı’nda öğrenim görenöğretmen adaylarının ise Özel Yetenek Sınıfları 
Oluşturma ( $\bar{X}=3.22)$ alt boyutuna ilişkin tutumları yüksek bulunmuştur. Sınıf öğretmenleri, çocukların 7 yaşından 11 yaşına kadar eğitimlerinden sorumlu olan ve onların ebeveynleri haricinde gün içinde en çok vakit geçirdikleri yetişkinlerden biridir. Çocukları bu kadar iyi tanıyan sınıf öğretmenlerinin onların bireysel farklılıklarına göre tutumlarında farklılık göstermesi ve onları desteklemesi gerekmektedir. Bu çalışmada da belirtilen sebeplerden dolayı sınıf öğretmenliği bölümünde öğrenim gören öğretmen adaylarının üstün yetenekliliğe ilişkin tutumlarının yüksek çıktığı, düşünülebilir. Lassig (2009) sınıf öğretmenleri ile yaptığı çalışmada sınıf öğretmenlerinin üstün yeteneklilerin eğitimine yönelik tutumlarının olumlu olduğunu ve üstün yetenekli çocuklarla çalışma sıklıkları arttıkça tutumlarının olumlu yönde arttığını belirtmiştir. Chipego (2004) yaptığı çalışmada sınıf öğretmenlerinin üstün yetenekli çocukların eğitimine ilişkin olumlu tutumlarının olduğuna ve olumlu tutumların sınıf içerisindeki sosyal kabülü olumlu yönde etkilediği sonucuna ulaşmıştır. Alfahaid (2002) sınıf öğretmenlerinin üstün yetenekli çocukların eğitimine ilişkin yaptığı çalışmada, çalışma grubundaki genç öğretmenlerin daha olumlu tutuma sahip olduğunu belirtmektedir. Megay - Nespoli (1998) ve Morrissey (2006) üstün yetenekli çocukların eğitimine yönelik eğitim alan öğretmen adaylarının tutumlarının olumlu olduğunu belirtmektedir. Gökdere ve Ayvacı (2004) sınıf öğretmenleri ile yaptıkları araştırmada bu bulguyu destekler sonuca ulaşmışlardır. $\mathrm{Bu}$ sonuçlara göre, öğretmenlerin büyük bir kısmı üstün yetenekli çocuklar için özel eğitimin gerekli olduğu ve hangi şartlarda olursa olsun bu çocukların kendilerini gösterecekleri ve geliştirebilecekleri fırsatlar sağlayan bir eğitim ortamı hazırlanması gerektiği görüşünü benimsemektedirler. İstatistiksel olarak da öğretmen adaylarının bölümlerine göre Üstün Yeteneklilerin İhtiyaçları ve Destek ve Üstün Yeteneklilere Özel Hizmetlere Karşı Olma boyutlarına ilişkin tutumları arasında anlamlı bir fark bulunmuştur $(\mathrm{p}<0.05)$.

Üstün Yeteneklilerin İhtiyaçları ve Destek alt boyutunda okul öncesi öğretmenliği ile sınıf öğretmenliği arasında; okul öncesi öğretmenliğinde öğrenim gören öğretmen adayları lehine; Türkçe ve Sınıf öğretmenliği arasında Türkçe öğretmenliğinde öğrenim gören öğretmen adayları lehine ve Türkçe ve sosyal bilgiler öğretmenliği arasında Türkçe öğretmenliğinde öğrenim gören öğretmen adayları lehine anlamlı farklılık bulunmuştur. Bu alt boyuttaki tutum ölçeğinden alınan ortalama puanlar 3.54 - 3.88 arasında değiştiği için öğretmen adaylarının Üstün Yeteneklilerin İhtiyaçları ve Destek alt boyutuna ilişkin tutumlarının olumlu düzeyde olduğu söylenebilir. Okul öncesi eğitimi programı, çocuk merkezli, çocukların mevcut potansiyellerini maksimum düzeye çıkarmayı amaçlayan, bireysel farklılıkları ön plana alan ve bireysel farklılı̆̆ olan çocuklar için uyarlama etkinliklerine yer veren bir programdır (MEB, 2013). Okul öncesi eğitim programında yüksek potansiyele sahip üstün yetenekli çocuklar için her etkinlik içinde uyarlama etkinlikleri hazırlanarak, diğer çocukların yaptıkları etkinlikten kopmadan bir üst beceri düzeyinde desteklenmesi sağlanır. Buradan hareketle okul öncesi öğretmenliği bölümündeki öğretmen adaylarının eğitim sürecinde üstün yetenekli çocukların gereksinimlerinin nasıl destekleneceğine ilişkin bilgiyi öğrendikleri ve bunu öğretmenlik uygulaması dersi kapsamında uyguladıkları için tutumlarının olumlu düzeyde olduğu düşünülmektedir. 
Öğretmenlerin sahip olması gereken nitelikler incelendiğinde bunların bazılarının öğrenciyi destekleme, öğrenciyle iş birliği içinde olma, öğrencinin tüm yönlerini tanıma, esnek bir eğitime sahip olma olduğu görülmektedir (Demirel, 2007). Diğer bölümlerde öğrenim gören öğretmen adaylarının, öğretmenlerin sahip olması gereken bu nitelikler doğrultusunda, üstün yetenekli çocukların okul ortamında gereksinimlerinin karşılanması ve desteklenmesi gerektiğini düşündükleri için olumlu tutuma sahip olabilecekleri varsayılmaktadır.

Üstün Yeteneklilere Özel Hizmetlere Karşı Olma alt boyutunda sosyal bilgiler öğretmenliği ile okul öncesi öğretmenliği ve sınıf öğretmenliği arasında sosyal bilgiler öğretmenliğinde öğrenim gören öğretmen adaylarının lehine anlamlı bir farklılık çıkmıştır. $\mathrm{Bu}$ alt boyutta öğretmen adaylarının bölümlerine göre tutum ölçeğinden aldıkları ortalama puanlar 3.41 - 3.76 arasında değiştiği için öğretmen adaylarının Üstün Yeteneklilere Özel Hizmetlere Karşı Olma alt boyutuna ilişkin tutumlarının olumlu düzeyde olduğu ifade edilebilir.

Öğretmen adaylarının bu alt boyuta yönelik tutumlarının olumlu düzeyde olması, üstün yetenekli çocukların gelişimsel özellikleri itibariyle farklı gereksinimlere sahip olduklarını bildikleri ve her bir çocuğun eğitimde eşitlik ilkesi kapsamında desteklenmesi gerektiğini düşündüklerinin göstergesi olabilir. Gökdere ve Ayvacı (2004) sınıf öğretmenleri ile yaptıkları araştırmada öğretmenlerin bir kısmının Bilim Sanat Merkezlerinin varlığından haberdar olmadığını bu nedenle üstün yetenekli çocuklara özel eğitim hizmeti verilmesine yönelik bilgilerinin olmadığını saptanmıştır. Şenol (2011) yaptığı çalışmada öğretmenlerin üstün yetenekli çocuklara özel bir hizmet sağlayan Bilim Sanat Merkezlerindeki eğitim programlarına yönelik olumlu tutum geliştirdikleri sonucuna ulaşmıştır. Ekinci (2002) tarafından yapılan araştırmada öğretmenler, ilköğretim okullarının üstün yetenekli çocukların eğitiminde, çocuklara yönelik özel hizmetler sağlama yönünden desteklemediğini; bu çocuklar için özel okulların olması gerektiğini belirtmiştir. Ancak Laschober (2012) öğretmen adaylarının üstün yeteneklilere yönelik tutumlarını ölçtüğü çalışmada, öğretmen adaylarının üstün yetenekli çocukların eğitiminde özel hizmetleri desteklediği sonuca ulaşmıştır.

Kurnaz, Tüybek ve Taşkesen'un (2009) araştırmasında, sınıf öğretmenlerinin eğitim programlarını ve verdikleri ödevlerin normal çocuklarla aynı olduğu sonucuna ulaşılarak; uygulanan eğitim programının üstün yetenekli çocuklara göre farklılaşması gerektiği vurgulanmıştır.

Ancak, öğretmen adaylarının bölümlerine göre Özel Yetenek Sınıfları Oluşturma alt boyutuna ilişkin tutumları arasında anlamlı bir fark bulunamamıştır $(\mathrm{p}>0.05)$. Tortop (2014a) da yaptığı çalışmada bu alt boyuta yönelik anlamlı farklılık bulamadığını belirtmiştir. $\mathrm{Bu}$ alt boyutta öğretmen adaylarının bölümlerine göre tutum ölçeğinden aldıkları ortalama puanlar 3.04 - 3.22 arasında değiştiği için öğretmen adaylarının Özel Yetenek Sınıfları Oluşturma alt boyutuna ilişkin tutumlarının kararsızlık düzeyinde olduğu ifade edilebilir. Öğretmen adayları "özel eğitim” dersi kapsamında özel gereksinimli bireylerin sınıf içinde kaynaştırılması, akranları ile aynı eğitim programını fakat çocukların özelliklerine göre farklılaştırılmış eğitim programının beraber işlenmesi 
gerektiğini öğrenmektedirler. Kısaca öğretmen adayları üstün yetenekli çocuklar için özel sınıflar oluşturulabileceği konusunda bilgi sahibi değildirler. Bu nedenle aynı okul içinde üstün yetenekli çocuklar için yetenek sınıfları oluşturulmasına yönelik kararsız tutum sergiledikleri söylenebilir. Güney Kore, İsrail gibi bazı ülkelerde başarı ile uygulanan özel yetenek sınıfları, çocukların normal akranları ile kaynaştırılmasını sağlamadığı için öğretmenler tarafından tercih edilmeyebilir (Türkiye Büyük Millet Meclisi, 2012). Ancak Ekinci (2002)'nin çalışmasında öğretmenlerin çoğunluğu ilköğretim okullarında özel sınıflar olması gerektiğine yönelik görüş belirtmişlerdir.

McCoach ve Siegle (2007) farklı branşlardaki öğretmenlerle yaptıkları çalışmada tüm branşlardaki öğretmenlerin üstün yetenekli çocukların eğitimine yönelik tutumlarının olumlu olduğu, üstün yetenekli çocuklarla ilgili eğitim alan öğretmenlerin tutumlarının almayanlara gore daha olumlu olduğu sonucuna ulaşmışlardır.

Araştırmanın bir diğer alt problemi olan "Öğretmen adaylarının üstün yetenekli eğitimine ilişkin tutumları cinsiyetlerine göre farklılaşmakta mıdır?” sorusuna ilişkin alt boyutlara göre anlamlı bir farkın olup olmadığı bağımsız örneklemler için t testi ile test edilmiş ve sonuçları Tablo 4'te gösterilmiştir.

Tablo 4

Öğretmen Adaylarının Üstün Yetenekli Çocukların Eğitimine Ilişkin Tutumlarının Cinsiyetlerine Göre t Testi Sonuçları

\begin{tabular}{|c|c|c|c|c|c|c|}
\hline ÜYETÖ & Cinsiyet & $n$ & Ortalama & $s s$ & $t$ & $p$ \\
\hline \multirow{3}{*}{$\begin{array}{l}\text { Üstün Yeteneklilerin İhtiyaçları ve } \\
\text { Destek }\end{array}$} & Erkek & 107 & 3.67 & 0.76 & \multirow{3}{*}{-1.295} & \multirow{3}{*}{0.196} \\
\hline & Kadın & 383 & 3.76 & 0.62 & & \\
\hline & Toplam & 490 & 3.74 & 0.66 & & \\
\hline \multirow{3}{*}{$\begin{array}{l}\text { Üstün Yeteneklilere Özel Hizmetlere } \\
\text { Karşı Olma }\end{array}$} & Erkek & 107 & 3.43 & 0.98 & \multirow{3}{*}{-2.795} & \multirow{3}{*}{$0.005^{*}$} \\
\hline & Kadın & 383 & 3.69 & 0.80 & & \\
\hline & Toplam & 490 & 3.63 & 0.85 & & \\
\hline \multirow[t]{3}{*}{ Özel Yetenek Sinıfları Oluşturma } & Erkek & 107 & 3.17 & 0.95 & \multirow[t]{3}{*}{1.245} & \multirow[t]{3}{*}{0.214} \\
\hline & Kadın & 383 & 3.06 & 0.77 & & \\
\hline & Toplam & 490 & 3.08 & 0.81 & & \\
\hline
\end{tabular}

$* \mathrm{p}<0.05$

Kadın öğretmen adaylarının Üstün Yeteneklilerin İhtiyaçları ve Destek ( $\bar{X}=3.76)$ ve Üstün Yeteneklilere Özel Hizmetlere Karşı Olma $(\bar{X}=3.69)$ boyutlarına ilişkin tutumları; erkek öğretmen adaylarının ise Özel Yetenek Sınıfları Oluşturma $(\bar{X}=3.17)$ alt boyutuna ilişsin tutumları yüksek bulunmuştur. Kadın ve erkek öğretmen adaylarının Üstün Yeteneklilerin İhtiyaçları ve Destek boyutu ile Üstün Yeteneklilere Özel Hizmetlere Karşı Olma boyutlarında tutum ölçeğinden aldıkları puanlar 3.43 - 3.76 arasında değişmekte olup bu alt boyutlara yönelik olumlu tutuma sahip oldukları 
görülmektedir. Özel Yetenek Sınıfları Oluşturma alt boyutuna ilişkin aldıkları puanlar 3.06 - 3.17 arasında değişmekte olup tutum puanları açısından kararsızlık durumuna sahip oldukları görülmektedir.

İstatistiksel olarak da öğretmen adaylarının cinsiyetlerine göre Üstün Yeteneklilere Özel Hizmetlere Karşı Olma boyutuna ilişkin tutumları arasında, kadınların lehine anlamlı bir fark bulunurken $(\mathrm{p}<0.05)$; Üstün Yeteneklilerin İhtiyaçları ve Destek ve Özel Yetenek Sınıfları Oluşturma alt boyutlarına ilişkin tutumları arasında anlamlı bir fark bulunamamıştır ( $p>0.05$ ). Ekinci (2002), Lassig (2009), Tortop (2014a), Tortop ve Kunt (2013) ve Troxclair (2013) öğretmenlerle yaptıkları çalışmalarda öğretmenlerin üstün yeteneklilerin eğitimine yönelik cinsiyet değişkenine ilişkin anlamlı bir farklılık çıkmadığını belirtmişlerdir. Al Garni (2012), Begin ve Gagné (1994), Chipego (2004), Curtis (2005), McCoach ve Siegle (2007) öğretmenlerin üstün yetenekli çocukların eğitimine yönelik tutumları üzerinde cinsiyetin etkili olmadığını belirtmişlerdir. $\mathrm{Bu}$ doğrultuda bu çalışmada da öğretmen adaylarının üstün yeteneklilerin eğitimine yönelik tutumlarında sadece Üstün Yeteneklilere Özel Hizmetlere Karşı Olma boyutuna ilişkin kadın cinsiyetinin anlamlı bir fark oluşturduğu, dolayısıyla kadınların erkeklere göre bu konuda daha duyarlı oldukları söylenebilir.

Araştırmanın bir diğer alt problemi olan "Öğretmen adaylarının üstün yetenekli eğitimine ilişkin tutumları kaynaştırma dersi alıp almamalarına göre farklılaşmakta mıdır?" sorusuna ilişkin alt boyutlara göre anlamlı bir farkın olup olmadığı bağımsız örneklemler için $\mathrm{t}$ testi ile test edilmiş ve sonuçları Tablo 5'te gösterilmiştir.

Tablo 5

Öğretmen Adaylarının Üstün Yetenekli Çocukların Eğitimine Ilişkin Tutumlarının Kaynaştırma Dersi Alıp Almama Durumlarına Göre T-Testi Sonuçları

\begin{tabular}{|c|c|c|c|c|c|c|}
\hline \multirow{2}{*}{$\ddot{U}$ UETÖ } & \multicolumn{6}{|l|}{ Kaynaştırma } \\
\hline & Dersi & $n$ & Ortalama & $s s$ & $t$ & $p$ \\
\hline \multirow{2}{*}{$\begin{array}{l}\text { Üstün Yeteneklilerin } \\
\text { İhtiyaçları ve Destek }\end{array}$} & Alan & 144 & 3.6637 & .642 & \multirow{2}{*}{-1.696} & \multirow{2}{*}{.840} \\
\hline & Almayan & 346 & 3.7737 & .659 & & \\
\hline \multirow{2}{*}{$\begin{array}{l}\text { Üstün Yeteneklilere Özel } \\
\text { Hizmetlere Karşı Olma }\end{array}$} & Alan & 144 & 3.6968 & .824 & \multirow{2}{*}{1.043} & \multirow{2}{*}{.862} \\
\hline & Almayan & 346 & 3.6089 & .860 & & \\
\hline \multirow{2}{*}{$\begin{array}{l}\text { Özel Yetenek Sinıfları } \\
\text { Oluşturma }\end{array}$} & Alan & 144 & 3.0434 & .749 & \multirow{2}{*}{-.750} & \multirow{2}{*}{$.035^{*}$} \\
\hline & Almayan & 346 & 3.1040 & .840 & & \\
\hline
\end{tabular}

$* \mathrm{p}<0.05$

Öğretmen adaylarının kaynaştırma dersi alıp almama durumlarına göre üstün yetenekli çocukların eğitimine ilişkin tutumları incelendiğinde, kaynaştırma dersi alan ve almayan öğretmen adayları arasında istatistiksel olarak "Üstün Yeteneklilerin İhtiyaçları ve Destek Boyutu” ve "Üstün Yeteneklilere Özel Hizmetlere Karşı Olma” alt boyutlarında anlamlı farklılık bulunmamıştır ve ölçekten aldıkları puanlar olumlu 
düzeyde olup ders alanlarla almayanların ortalama puanları arasında çok büyük bir farklılık bulunmamaktadır.

Ancak istatiksel olarak "Özel Yetenek Sınıfları Oluşturma” alt boyutuna ilişkin kaynaştırma dersi alan ve almayan öğretmen adayları arasında, ders almayan öğretmen adaylarının lehine anlamlı farklılık bulunmuştur. Kaynaştırma dersi almayan öğretmen adaylarının ölçekten aldıkları puan daha yüksek $(\bar{X}=3,104)$ çıkmış olup, ders alan ve almayan öğretmen adaylarının tutumları kararsızlık düzeyinde çıkmıştır. Shippen, Crites, Houchins, Ramsey ve Simon (2005) kaynaştırma eğitimi alan öğretmen adayları ile yaptıkları çalışmanın sonucunda kaynaştırma eğitimi alan öğretmen adaylarının üstün yetenekli çocukların kaynaştırılmasına yönelik olumlu tutuma sahip olduğu sonucuna ulaşmışlardır. Al Garni'nin (2012) özel eğitim öğretmen adayları ile yaptığı çalışmada kullanılan yöntem ve tekniklerde üstün yetenekli çocuklara uygun uyarlamalar yapılırsa kaynaştırma uygulamasına dahil edilmesi gerektiğini vurgulamaktadır ve öğretmen adaylarının kaynaştırma eğitiminin uygulanmasına ilişkin tutumlarının olumlu olduğu sonucuna ulaşmıştır. Tortop'a (2014b) göre, kaynaştırma uygulaması, bilimsel ve akademik çalışmalarla katkısı ortaya konulan bir uygulama iken kaynaştırmadaki yanlış uygulamalar nedeniyle özel gereksinimi olan bireylere eğitimsel açıdan yeterli bir uygulama yapılamadığında, kaynaştırmaya ilişkin tutum olumsuz ya da yansı/kararsız olabilmektedir. Bu durum teorik ve idealde olanın uygulamada karşılığının olmaması ya da yetersiz olması nedeniyle tutumlardaki karışıklığın ifadesidir. Cross, Cross ve Frazier'in (2013) yaptıkları çalışmada üstün yetenekli çocukların kaynaştırma sınıfında ve özel yetenek sınıfında bir süre eğitim aldıktan sonraki akademik başarıları, sosyal becerileri ve öğretmen tutumları incelenmiştir. Çalışmanın sonucunda özel yetenek sınıfinda eğitim alan çocukların akademik başarılarının, kaynaştırma sınıflarında eğitim alan çocukların sosyal becerilerinin gelişmiş olduğu ve her iki sınıftaki öğretmen tutumunun olumlu belirtilmiştir.

Toplumun genel yargısına paralellik gösterecek şekilde kaynaştırma dersini almayan öğrenciler, ayrıştırılmış ya da izole edilmiş sınıflara özel gereksinimli çocukların yerleştirilmesinin daha faydalı olacağını düşünmüş olabilecekleri akla gelmektedir. Çünkü özel gereksinimli diğer çocuklar gibi üstün yetenekli çocuklar da öğretmenlerin "ne yapacaklarını bilmedikleri” için normal sınıflarda karşılaşılmak istenmeyen bir gruptur. $\mathrm{Bu}$ çocukların normal gelişenlerle nasıl bir araya gelebileceklerine ilişkin bilgisi olmayan öğretmen adaylarının kaynaştırmadan ziyade özel yetenek sınıflarında eğitilmeleri yönünde bir fikir geliştirdikleri düşünülmektedir. Ayrıca kaynaştırma dersi kapsamında kaynaştırmanın öneminin anlatılması, tüm özel gereksinimli çocukların normal akranlarıyla birlikte olma ve eğitime katılma haklarının hatırlatılması nedeniyle çalışmada, bu dersi alan öğretmen adaylarında (okul öncesi öğretmenleri), üstün yetenekli çocuklara özel yetenek sınıfları oluşturma boyutunda daha düşük bir ortalama elde edilmiş olabilir. Ataman'a (2005) göre, araştırmalar, özel sınıf uygulamasının ilköğretimden ziyade orta öğretimde özellikle çok üstün ve yaratıcı çocuklar için uygulanabilir olduğunu ifade etmektedir. Yararları ve sakıncaları dikkate alınarak ögrenci sayısı fazla olan okullarda ve bir veya birden fazla zekâ alanlarında 
üstün yetenekli olan çocuklar, kredili sistem uygulanması koşulu ile bu uygulamadan faydalanabilirler.

\section{Tartışma ve Sonuç}

Öğretmen adaylarının üstün yetenekli çocuklara yönelik tutumlarının ölçüldüğü bu çalışmada aşağıdaki sonuçlara ulaşılmıştır:

- Öğretmen adaylarının ölçeğin geneline ilişkin ölçek puanlarının ortalaması ( $\bar{X}=3.53)$ ve Üstün Yeteneklilerin İhtiyaçları ve Destek Boyutuna ilişkin ölçek puanlarının ortalaması ( $\bar{X}=3.74)$; Üstün Yeteneklilere Özel Hizmetlere Karşı Olma boyutuna ilişkin ölçek puanlarının ortalaması $(\bar{X}=3.63)$; Özel Yetenek Sınıfları Oluşturma boyutuna ilişkin ölçek puanlarının ortalaması $(\bar{X}=3.09)$ olup tutumları olumlu veya kararsızlık düzeyindedir.

- Öğretmen adaylarının üstün yetenekli eğitimine ilişkin tutumları öğrenim gördükleri bölüme göre incelendiğinde; Üstün Yeteneklilerin İhtiyaçları ve Destek ve Üstün Yeteneklilere Özel Hizmetlere Karşı Olma boyutlarına ilişkin tutumları arasında anlamlı bir fark bulunurken; Özel Yetenek Sinıfları Oluşturma alt boyutuna ilişkin tutumları arasında anlamlı bir fark bulunamamıştır.

- Öğretmen adaylarının cinsiyetlerine göre Üstün Yeteneklilere Özel Hizmetlere Karşı Olma boyutuna ilişkin tutumları arasında, kadınların lehine anlamlı bir fark bulunmuştur $(\mathrm{p}<0.05)$. Ancak, Üstün Yeteneklilerin İhtiyaçları ve Destek ve Özel Yetenek Sınıfları Oluşturma alt boyutlarına ilişkin tutumları arasında anlamlı bir fark bulunamamıştır.

- Öğretmen adaylarının üstün yetenekli eğitimine ilişkin tutumları kaynaştırma dersi alıp almama durumlarına göre incelendiğinde; Üstün Yeteneklilerin İhtiyaçları ve Destek ve Üstün Yeteneklilere Özel Hizmetlere Karşı Olma boyutlarına ilişkin tutumları arasında anlamlı bir fark bulunamamıştır; Özel Yetenek Sınıfları Oluşturma alt boyutuna ilişkin tutumları arasında anlamlı bir fark bulunmuştur.

Araştırmanın sonuçları doğrultusunda öğretmen adaylarının kararsızlık düzeyinde olan tutumlarının yükseltilmesi için destekleyici eğitim programları oluşturulabilir.

Eğitim fakültelerinin tüm bölümlerinde özel eğitim dersi gibi kaynaştırma dersi de zorunlu hale getirilebilir ve derslerin içeriği öğretmen adaylarının olumlu tutum geliştirmelerini sağlayacak şekilde düzenlenebilir. Ayrıca bazı bölümlerdeki öğretmenlik eğitimi programında bulunan Kaynaştırma dersi kapsamında özel gereksinimli çocukların kaynaştırma eğitiminden yararlanabilecekleri, bunun yanı sıra, özellikle üstün yetenekli çocukların normal akranlarından farklı olan ilgi ve gereksinimlerine yönelik oluşturulmuş özel yetenek sınıflarının kendi gibi akranlarıyla bilgi alışverişi, deneyimlerin paylaşılması ve yaratıcılıklarının gelişmesi için gerekli olduğu bilgisi verilebilir. 
Bunun yanı sıra öğretmenlik eğitimlerinin son sınıfinda veya mezun olduktan sonra katılabilecekleri üstün yeteneklilerin eğitimine yönelik Milli Eğitim Bakanlığ 1 tarafindan sertifika programları açılabilir. Belirtilan sertifika programının öğretmenlere ve üstün yetenekli çocuklara yüksek düzeyde katkısının olacağı düşünülmektedir. Üstün yetenekli çocukların eğitimine yönelik sertifika programlarının dünyada birçok örneği bulunmakta olup üstün yetenekli çocukların eğitimlerinin daha profesyonelce yürütüldüğü görülmektedir (Mönks \& Pflüger, 2005). Diğer ülkelerdeki iyi uygulama örnekleri göz önünde bulundurularak ve ülkemiz gerçekleri ve gereksinimleri temel alınarak yeni modeller ya da sertifika programları oluşturulabilir. Oluşturulan programları, öğretmenlerin üstün yetenekli çocukların eğitimine yönelik bilgi düzeylerini ve tutumlarını olumlu yönde etkileyecek şekilde tasarlanabilir. 


\section{Kaynakça}

Akar, İ. \& Akar, Ş.Ş. (2012). İlköğretim okullarında görev yapmakta olan öğretmenlerin üstün yetenek kavramı hakkındaki görüşleri. Kastamonu Eğitim Dergisi, 20(2), 423-436.

Al Garni, A.A. (2012). Attitudes of future special education teachers toward gifted students and their education (Unpublished doctoral dissertation). Queensland University of Technology, Brisbane, Australia.

Albion, P.R. \& Entmer, P.A. (2002). Beyond the foundation. The role of vision and belief in teachers' preparation for integration of technology. TechTrends, 46(5), 3438.

Alfahaid, S.S. (2002). A study of gifted education in Saudi Arabia: Teachers' and administrators' attitudes and the impact of the gifted identification training program (Doctoral Dissertation). The Pennsylvania State University, Pennsylvania, United States.

Allodi, M.W. \& Rydelius, P. (2008, September). Gifted children their school environments, mental health and specific needs: A study of Swedish teachers' knowledge and attitudes. Paper presented at the European Council for High Ability Conference, Prague, Czech Republic.

Ataman, A. (2005). Üstün zekâlı ve üstün yetenekli çocuklar. A. Ataman (Ed.) içinde, Özel Gereksinimli çocuklar ve Özel Eğitime Giriş (283 - 306). Ankara: Gündüz Eğitim ve Yayıncıllk.

Begin, J. \& Gagné, F. (1994). Predictors of a general attitude toward gifted education. Journal for the Education of the Gifted, 18(1), 74-86.

Bianco, M. (2005). The effects of disability labels on special education and general education teachers' referrals for gifted programs. Learning Disability Quarterly, 28 (4), 285-29.

Çapan, B.E. (2010). Öğretmen adaylarının üstün yetenekli öğrencilere ilişkin metaforik algıları. Uluslararası Sosyal Araştırmalar Dergisi, 3(12), 140-154.

Çaylak, B. (2012). Fen ve teknoloji ögretmen adaylarının üstün yetenekli ögrrenciler ve eğitimleri hakkındaki görüşleri. 3. Türkiye Üstün Yetenekli Çocuklar Kongresi. 6875, Ankara, Hacettepe Üniversitesi Kültür ve Kongre Merkezi.

Chipego, A. (2004). Factors associated with the attitudes of elementary level classroom teachers toward gifted education (Unpublished doctoral dissertation). Widener University, Chester.

Clark, B. (1997). Growing up gifted. Developing the potential of children at home and at school (5th ed.). NJ: Merill, Upper Saddle River.

Cline, S. \& Schwartz, D. (1999). Diverse populations of gifted children. Upper saddle River, NJ: Prentice-Hall.

Clinkenbeard, P.R. \& Kollhoff, P.B. (2001). Ten suggestions for including gifted education in preservice teacher education. The Teacher Educator, 36(3), 214-216. 
Cross, J.R., Cross, T. \& Frazier, A.D. (2013). Student and teacher attitudes toward giftedness in a two laboratory school environment: A case for conducting a needs assessment. NALS Journal, 5(1), 1-21.

Curtis, J. (2005). Preservice teacher' attitudes toward gifted students and gifted education (Unpublished doctoral dissertation). Columbia University, USA.

Demirel, Ö. (2007). Öğretimde planlama ve değerlendirme ögretme sanatı. (11. Bask1). İstanbul: Pegem Yayınc1lı.

Donerlson, E.R. (2008). Elementary school teachers' attitudes and beliefs toward teaching gifted students in heterogeneous classrooms (Unpublished doctoral dissertation). Walden University, Washington.

Ekinci, A. (2002). Illköğretim okullarının üstün yetenekli çocukların eğitimine elverişlilik düzeyi ile ilgili ögretmen görüşlerinin değgerlendirilmesi (Yayımlanmamış yüksek lisans tezi). Dicle Üniversitesi, Diyarbakır.

Esposito, C. (1999). Learning in urban blight: school climate and its effects on the school performance of urban, minority, low-income children. School Psychology Review, 28(3), 365-377.

Gagne, F. \& Nadeau, L. (1985). Dimensions of attitudes toward giftedness. In A. H. Roldan (Eds), Gifted and talented children, youth and adults: Their social perspective and culture (pp. 148-170). NY: Trillium Press.

Gagné, F. (1991). Brief presentation of Gagné and Nadeau's attitude scale: Opinions about the gifted and their education. Montreal: University of Québec.

Gerow, J., Bordens, K. \& Blanche-Payne, E. (2007). General psychology with spotlights on diversity. NV: Bent Tree Press.

Goodwin, A.L. (2002). The case of one child: making the shift from personal knowledge to professionally informed practice. Teaching Education, 13(2), 137154.

Gökdere, M. \& Ayvacı, H.S. (2004). Sınıf öğretmenlerinin üstün yetenekli çocuklar ve özellikleri ile ilgili bilgi seviyelerinin belirlenmesi. Ondokuz Mayı Üniversitesi Eğitim Fakültesi Dergisi, 18, 17-26.

Yakmac1 Güzel, B. (2009). Türk öğretmenlerinin üstün yeteneklilerin eğitimi konusundaki görüşleri. Üstün Yetenekli Çocuklar II. Ulusal Kongresi. 80-81, Eskişehir, Anadolu Üniversitesi Kongre Merkezi.

Hansen, J.B. \& Feldhusen, J.F. (1994). Comparison of trained and untrained teachers of gifted students. Gifted Child Quarterly, 38(3), 115-121.

Karasar, N. (2005). Bilimsel araştırma yöntemi. Ankara: Nobel Yayın Dağıtım.

Kaya, N.G. \& Ataman, A. (2012). Üstün yetenekli ögrencilerin eğitiminde bilim ve sanat merkezlerinin yeri ve önemi. 3. Türkiye Üstün Yetenekli Çocuklar Kongresi. 17-23, Ankara, Hacettepe Üniversitesi Kültür ve Kongre Merkezi.

Kıldan, A.O. (2011). Okul öncesi öğretmenlerinin üstün yetenekli çocuklar hakkındaki görüşleri. Kastamonu Eğitim Dergisi, 19(3), 805-818. 
Kurnaz, A., Tüybek, C. \& Taşkesen, Ü.S. (2009). Sınıf öğretmenlerinin üstün yetenekli ögrencilere ilişkin görüş ve uygulamaları. Üstün Yetenekli Çocuklar II. Ulusal Kongresi. 81-82, Eskişehir, Anadolu Üniversitesi Kongre Merkezi.

Laschober, Z. (2012). Perceptions of preservice teacher candidates towards gifted education training and obtaining the gifted education endorsement certificate in Florida (Unpublished master thesis). University of Central Florida, Orland.

Lassig, C.J. (2003). Teachers' attitudes towards intellectually gifted children and their education (Unpublished master thesis). Griffith University, Queensland, Australia.

Lassig, C.J. (2009). Teachers' attitudes towards the gifted: the importance of professional development and school culture. Australasian Journal of Gifted Education, 18(2), 32-42.

Levent, F. (2014). Üstün yetenekli çocukları anlamak (2. Bask1). Ankara: Nobel Yayınları.

Maker, J.N. \& Nelson, A.B. (1996). Curriculum development and teaching strategies gifted students (2nd ed.). Austin, Texas: Pro-Ed.

McCoach, B. \& Seigle, D. (2007). What predicts teachers' attitudes toward the gifted? Gifted Child Quarterly, 51, 246-255.

MEB. (2013). Okul öncesi eğitim programı. Ankara: MEB Basımevi.

Megay-Nespoli, K.P. (1998). Beliefs and attitudes of novice teachers regarding instruction of academically talented learners (Unpublished doctoral dissertation). Columbia University Teachers College, New York, United States.

Megay-Nespoli, K. (2001). Beliefs and attitudes of novice teachers regarding instruction of academically talented learners. Roeper Review, 23, 178-182.

Morris, S.K. (1987). Student teachers' attitudes toward gifted students. The Creative Child and Adult Quarterly, 12(2), 112-114.

Morrissey, M.L. (2006). Intervention training with a focus on differentiated curriculum and teachers' attitudes toward the gifted in regular elementary school classrooms. (Unpublished doctoral dissertation). Columbia University Teachers College, New York, United States.

Mönks, F.J. \& Pflüger, R. (2005). Gifted education in 21 European countries: inventory and perspective. Radboud University Nijmegen, Netherlands.

Neumeister, K.L.S., Adams, C.M., Pierce, R.L., \& Cassidy, J.C. (2007). Fourth-grade teachers'perceptions of giftedness: Implications for identifying and serving diverse gifted students. Journal for the Education of the Gifted, 30(4), 479-499.

Rao, S. \& Lim, L. (1999, May). Beliefs and attitudes of pre-service teachers towards teaching children with disabilities. The 123rd Annual Conference of the American Association on Mental Retardation, New Orleans, LA .

Rash, P.K. \& April D.M. (2000). A survey of practices of teachers of the gifted. Roeper Review, 22(3), 192-194 
Robinson, A., Shore, B. M. \& Enersen, D. L. (2014). Üstün zekalılar eğitiminde en iyi uygulamalar (Ü. Ogurlu \& F. Kaya, Çev.). Ankara: Nobel Yayınevi.

Sak, U. (2011). Üstün yetenekliler eğitim programları modeli (ÜYEP) ve sosyal geçerliliği. Eğitim ve Bilim, 36(161), 213-229.

Shippen, M., Crites, S., Houchins, D., Ramsey, M. \& Simon, M. (2005). Preservice teachers' perceptions of including students with disabilities. Teacher Education and Special Education, 28(2), 92-99.

Siegle, D. \& McCoach, B. (2004, April). Opinions about the gifted and their education. Paper presented at the American Education Research Association Annual Meeting, Montreal, Canada.

Şenol, C. (2011). Üstün yetenekliler eğitim programlarına ilişkin ögrretmen görüşleri (BILLSEM örneği) (Yayınlanmamış yüksek lisans tezi). Fırat Üniversitesi, Elazı̆̆.

Şentürk, Ş., Bayat, S., \& Kilıçarslan, H. (2012). Üstün yetenekli çocukların eğitimlerinde karşılaşılan sorunlar. 3. Türkiye Üstün Yetenekli Çocuklar Kongresi. Mevcut Durum, Gereksinimler ve Geleceğe Bakış Bildiriler Kitabı (ss. 9-16). Ankara: Hacettepe Üniversitesi Yayınları.

Türkiye Büyük Millet Meclisi (2012). Üstün yetenekli çocukların keşfi, eğitimleriyle ilgili sorunların tespiti ve ülkemizin gelişimine katkı sağlayacak etkin istihdamlarının sağlanması amacıyla kurulan meclis araştırması komisyonu raporu. 24. Dönem, 3. Yasama Y1l, http://oyemer.uskudar.edu.tr/uploads/file/yonerge.pdf sitesinden 29.07.2016 tarihinde indirilmiştir.

Tomlinson, C. (1996). Good teaching for one and all: Does gifted education have an instructional identity? Journal for the Education of the Gifted, 20, 155-174.

Tortop, H.S. (2012). Öğretmenler için üstün yeteneklilerin eğitimine ilişkin tutum ölçeği adaptasyon çalışması. Erzincan Üniversitesi Sosyal Bilimler Enstitüsü Dergisi, 5(1), 89-106.

Tortop, H.S. \& Kunt, K. (2013). İlköğretim öğretmenlerinin üstün yeteneklilerin eğitimine ilişkin tutumlarının incelenmesi. International Online Journal of Educational Sciences, 5(2), 441-451.

Tortop, H.S. (2014a). Öğretmen adaylarının üstün yetenekli ve çok kültürlü eğitime ilişkin tutumları. Üstün Yetenekliler Eğitimi Araştırmaları Dergisi, 2(2), 16-26.

Tortop, H.S. (2014b). Öğretmenler için üstün yetenekli eğitime ilişkin tutum ölçeği Türkiye için uyarlama çalışmasının yeniden gözden geçirilmesi. Üstün Yetenekliler Eğitimi Araştırmaları Dergisi, 2(2), 63-71.

Troxclair, D.A. (2013). Preservice teacher attitudes toward giftedness. Roeper Review, 35(1), 58-64.

Winebrenner, S. (2001). Teaching gifted kids in regular classroom. Minnespolis: Free Spirit Publishing Inc. 